\title{
The stimulating function of betting and gambling tax in theoretical terms and in the assumptions of the Polish legislator
}

\begin{abstract}
The article addresses the issues of the stimulating (intervention) function of the betting and gambling tax. It attempts to answer the question whether the intention of the Polish legislator was to ascribe this function to the betting and gambling tax, and if so, to what extent such assumptions were reflected in the legal provisions and the resulting norms.

The first part of the article identifies the basic levels of the performance of the stimulating function of the betting and gambling tax in theoretical terms. The second part presents the functions that were attributed to the lottery monopoly and the taxes that affected the organisation of gambling games in the interwar period and in the Polish People's Republic. The third part of the article analyses the provisions of the Act on Games and Mutual Wagering as well as the Gambling Law in the context of the extent to which these regulations were expected to have an interventional effect at the drafting and adoption stage.
\end{abstract}

Keywords: betting and gambling tax, stimulating function of tax, gambling

1 Michalina Duda-Hyz, PhD - assistant professor at the Department of Finance and Finance Law, the John Paul II Catholic University of Lublin; e-mail: dudami@kul.lublin.pl 


\section{Introductory remarks}

Although the betting and gambling tax in its current form has been in force in Poland since 1992 and its origins can be traced back to the lottery rack, the traditions of which date back to the $18^{\text {th }}$ century, ${ }^{2}$ the issues associated with taxing the organisation of gambling is extremely rare. One of the issues that has not been addressed in the contemporary legal theory of the Polish tax law, but undoubtedly deserves scientific reflection, is the question of non-fiscal functions attributed to this tax. The main purpose of this paper is to attempt to partially fill the gap in the above-mentioned matter, with the task being carried out in two dimensions. The first dimension involves indicating the basic dimensions of performance of the stimulating (intervention) function of betting and gambling tax in theoretical terms. The second dimension covers the analysis of the content of the provisions of the Polish tax law and related legislative materials with a view to explaining the extent to which their intervention-related impact was assumed at the stage of drafting and adopting these regulations. Because the issues of functions performed by the tax system and individual taxes are of interest to representatives of various scientific disciplines and the concept of financial and hence tax function alone is recognised variously in the legal and financial literature, the performance of the research task outlined above necessitates some preliminary assumptions.

First of all, a reference should be made to the very concept of the tax function. On the one hand, a view is expressed in the legal theory of financial law that financial functions, and hence also tax functions, originate from the very essence of finance as an economic phenomenon, and therefore are objective and independent of human will, which, however, does not exclude the possibility of their conscious use in the course of financial activities. ${ }^{3}$ In such an approach, tax functions are

2 For more see: Z. Ofiarski, Opodatkowanie działalności w zakresie urządzania loterii - reminiscencje z okresu II Rzeczypospolitej oraz czasy wspótczesne, [in:] C. Kosikowski (ed.), Prawo skarbowe i prawo finansowe. Szkoły i uczniowie. Księga dedykowana pamięci Profesora Jerzego Lubowickiego, Białystok 2013, pp. 141-157; M. Duda-Hyz, Loterie jako instrumenty pozyskiwania dochodów państwa w polskim prawie skarbowym w latach 1768-1871, “Czasopismo Prawno-Historyczne” 2017, 69(2), pp. 89-109.

3 See. M. Weralski, Instrumenty prawno-finansowe, [in:] idem, System instytucji prawno-finansowych PRL, Vol. 1, Instytucje ogólne, Wrocław 1982, pp. 211. From more on various function concepts, see: E. Tegler, Funkcje systemu podatkowego i cena jego sprawności, "Acta Universitatis Lodziensis. Folia Iuridica" 1992, 54, pp. 101-109. 
immanently connected with its essence, whereas the financial system, as a financial and legal institution, does not fulfil any objective function. ${ }^{4}$ On the other hand, tax functions are identified with the goals and tasks to be achieved through taxation, which in turn leads to a conclusion that an appropriate tax structure makes it possible to achieve many various objectives of the state policy. ${ }^{5}$ The assumption that taxes - and thus the functions performed by them as well - should be analysed not only as an economic category, but also as a legal and systemic phenomenon entails the need to take into account the role these instruments play in the implementation of fiscal policy, hence advocating the acceptance of the second of the above-mentioned views.

Secondly, it should be pointed out that the functions assigned to tax systems or individual taxes may be of interest to representatives of various scientific disciplines, which of course results from the features of phenomena and processes that occur in connection with the creation, accumulation and distribution of public funds. What is also important with regard to betting and gambling taxes, apart from the obvious economic aspect. ${ }^{6}$ determined by the objective nature of the category of public finances is the social aspect resulting from the specifics of gambling. Research on the implementation of external tax policy objectives by means of various taxes on gambling is therefore consistent with the trend of interdisciplinary gambling studies. This paper focuses on the analysis of the stimulating function in the legal aspect by attempting to answer the question whether the intention of the legislator was to assign the function in question to the betting and gambling tax, and if so, to what extent the above assumptions were reflected in regulations and the resulting standards. It was assumed in accordance with the view established in the jurisprudence that the stimulating function, including economic and non-economic incentives, boils down to stimulating or enhancing phenomena beneficial to society and the national economy by means of tax schemes and to inhibiting or eliminating harmful phenomena. ${ }^{7}$

4 See: E. Tegler, op. cit., p. 108.

5 See N. Gajl, Teorie podatkowe w świecie, Warszawa 1992, pp. 124-125. This seems to be the most popular view in the Polish jurisprudence. For more see: M. Duda, Kontrowersje dotyczace redystrybucyjnej funkcji podatków. Wybrane zagadnienia, "Roczniki Naukowe Wyższej Szkoły Bankowej w Toruniu" 2009, 8, p. 227 and the literature referred to therein.

6 See: S. Owsiak, Finanse publiczne. Teoria i praktyka, Warszawa 1997, p. 26.

7 See J. Gluchowski, Polskie prawo podatkowe, Warszawa 2004, pp. 19-20; W. Wójtowicz, Pojęcie i charakter podatku jako dochodu publicznego, [in:] P. Smoleń, W. Wójtowicz (eds.), Prawo podatkowe, Warszawa 2017, p. 28. 


\section{Dimensions of performance of the betting and gambling tax stimulating function}

The basic non-fiscal function that can be attributed to modern taxes on gambling is the stimulating function. In the Polish jurisprudence, the most popular view is that betting and gambling taxes, in particular in the form of selective turnover taxes, are a convenient instrument for shaping human behaviour, and one of their primary goals is to discourage consumption, which is perceived as unproductive, unnecessary and harmful. ${ }^{8}$ In the English literature, betting and gambling taxes are even referred to as "sin taxes" or "taxes on vices", 9 which clearly indicates the perception of the social phenomenon of gambling, and indirectly also the functions that are associated with these levies. Betting and gambling taxes, just like some types of excise duties and environmental fees, may therefore reduce the demand for gambling services through the impact on the price of the services offered (negative incentives). In this context, it should be added that expenses on gambling are assessed as unproductive because the redistribution of the wealth at risk is made only between entities that are parties to concluded gambling and betting contracts. ${ }^{10}$ Despite the changing standards and lifestyle, the consumption of gambling services continues to be perceived as unnecessary in many environments, while the threats related to the possible problematic behaviour among players are the main reason for recognising it as socially harmful.

The second dimension of performance of the stimulating function in a negative sense involves limiting the supply of such services by imposing higher taxes on the entities operating a gambling business than those applied in other branches of the economy. ${ }^{11}$ Therefore, betting and gambling taxes can be used to achieve the

8 See for instance: W.N. Thompson, Gambling Taxes: The Philosophy, the Constitution and Horizontal Equity, "Jeffrey S. Moorad Sports Law Journal” 2010, 17(2), p. 18; V. Vermeed, R. van der Ploeg, J.W. Timmer, Taxes and the Economy. A Survey on the Impact of Taxes on Growth, Employment, Investment, Consumption and the Environment, Northampton 2009, p. 210; Ch.T. Clotfelter, Gambling Taxes, [in:] S. Cnossen (ed.), Economics and Politics of Excise Taxation. Smoking, Drinking, Gambling, Polluting and Driving, Oxford 2005, p. 85; P. Lorenzi, Taxing Antisocial Behavior for the Common Good, "Society" 2010, 47, pp. 328-332. The impact of gaming tax on the level of consumption of gambling services is also the subject of economic research. See for instance: P.J. Harvey, J.P. Swayze, W.D. Walls, The Revealed Revenue Effects of Gambling Taxation: Logit Analysis of Better Behavior in a Laboratory Casino, "International Journal of Management" 2004, 21(4), pp. 407-412.

9 See for instance: R.W. McGee, The Philosophy of Taxation and Public Finance, Boston-DordrechtLondon 2004, p. 233; D.P. O’Brien, J. Creedy (eds.), Taxation and Promotion of Human Happiness. An Essay by George Warde Norman, Cheltenham-Northampton 2009, p. 167.

10 See P. Collins, Gambling and the Public Interest, Westport-London 2003, p. 342.

11 See W.D. Samson, History of Taxation, [in:] A. Lymer, J. Hasseldine (eds.), The International Taxation System, Boston-Dordrecht-London 2002, p. 33. 
goal of reducing the number of offered gambling services, and hence they are an instrument to protect and improve the well-being of society. ${ }^{12}$ It seems that the stimulating function in this aspect may also be perceived as one of the elements to regulate gambling in the strict sense, i.e. understood as a restrictive public intervention consisting in ensuring that certain spheres of social and economic life function in accordance with the public interest. ${ }^{13}$ As already mentioned, the assignment of the stimulating function to gaming taxes by limiting the demand and supply of gambling services is justified by the conviction that gambling is unproductive activity aimed at gaining profits. However, it should be noted that the positions formulated in this area by representatives of economic sciences are not unambiguous. The opinions about the activity of professional players for whom gambling constitutes a source of income differ in particular. ${ }^{14}$ In the context of the stimulating function consisting in inhibiting and eradicating the phenomena unfavourable for society and the economy, it is also pointed out that there are problems resulting from the demographic structure of persons participating in gambling who are more vulnerable to the negative effects of gambling. On the one hand, taxes on gambling in the form of selective turnover taxes are regressive, which means that they affect to a greater degree less affluent people, who, in extreme cases, may give up the purchase of other important products and services in order to be able to participate in gambling. ${ }^{15}$ On the other hand, social science studies confirm the thesis that one of the factors affecting the risk of developing problematic behaviours is the low socio-economic position of the players, which leads to the conclusion that it is reasonable to limit consumption, which raises particular risks for disadvantaged people. ${ }^{16}$ Assuming that betting and gambling tax is to fulfil the function of limiting the phenomena that are unfavourable for the economy and society, one should

12 Cf. S. Miller, C. Ludeña, Protecting Goods by Taxing "Bads", [in:] A. Corbacho, V. F. Cibils, E. Lora (eds.), More than Revenue. Taxation as a development tool, New York 2013, p. 195.

13 L. Wilk, W sprawie zakazu hazardu niereglamentowanego, "Państwo i Prawo" 2013, 4, pp. 60-61.

14 For more on various assessments of gambling, see D.S. Walker, The Economics of Casino Gambling, Berlin-Heidelberg 2007, pp. 152-156 and the literature referred to therein.

15 For more see D. Halliday, Egalitarianism and Consumption Tax, [in:] H.P. Gaisbauer, G. Schweiger, C. Sedmak (eds.), Philosophical Explorations of Justice and Taxation. National Global Issues, Cham-Heidelberg-New York-Dordrecht-London 2015, pp. 124-126; D.B. Suits, Gambling Taxes: Regressivity and Revenue Potential, "National Tax Journal" 1977, 30, pp. 19-35.

16 For more on the studies confirming the above-mentioned relationship, see for instance: J.W. Welte, G.M. Barnes, W.F. Wieczorek, et al., Gambling Participation in the U.S. - Results from a National Survey, "Journal of Gambling Studies" 2002, 18(4), pp. 313-337; G. Saad, The Evolutionary Basis of Consumption, Mahwah, N.J.-London 2007, pp. 248-249; J.P. Whelan, T.A. Steenbergh, A.W. Meyers, Problem and Pathological Gambling, Toronto 2007, e-book and the literature referred to therein. 
take into account both the regressive nature of this levy as well as the economic and social determinants of gambling.

The third dimension of the performance of the stimulating function of gaming taxes is essentially different from those indicated above, as it involves encouraging some forms of gambling through the use of tax advantages, first of all in the form of tax exemptions or reduced tax rates (positive incentives). In the economic practice of countries of Western culture, such solutions apply primarily to gambling organised for public benefit purposes, with tax advantages in the form of tax exemptions most often being used by entities organising "charity lotteries" ${ }^{17}$ Betting and gambling tax schemes can also be used to stimulate certain sectors of the gambling market, e.g. the betting sector or the online gambling sector.

\section{Non-fiscal functions of the betting and gambling tax in the Polish legal tradition}

The taxation of gambling, just like the taxation of winnings from this type of gambling and lotteries, is undoubtedly one of the instruments to determine the state's gambling policy. Depending on how gambling is perceived as a social phenomenon, various functions are attributed to betting and gambling taxes; however, it should be stressed that this type of levy clearly shows the pursuit of non-fiscal goals, in particular an attempt to reduce the scale of gambling. In the nineteenth century and in the interwar period, both in the Polish and Western literature, the most popular view was that gambling is a form of human activity that is morally reprehensible and entails a number of social threats, and therefore any activity in this area as a rule should not be perceived by public-law institutions as an effective and stable source of budget revenues. ${ }^{18}$ To justify the need for a state lottery monopoly, it was explained that it was necessary to prevent foreign lotteries from entering the country and to develop private lotteries that could "arouse the passion for gambling", while criticising measures aimed at strengthening the fiscal efficiency

17 For more see M. Duda, Urzadzanie loterii charytatywnych jako przedmiot preferencyjnego opodatkowania podatkami od gier, [in:] B. Kucia-Guściora, M. Münnich, A. Zdunek (eds.), Stanowienie i stosowanie prawa podatkowego w Polsce. Sankcje i preferencje w prawie podatkowym, Lublin 2015, pp. 173-191 and the literature referred to therein.

18 For more see G. Reith, The Age of Chance. Gambling in Western Culture, London-New York 1999, pp. 5-6; J. McMillen, Understanding Gambling. History, concepts and theories, [in:] idem (ed.), Gambling Cultures, London 1996, pp. 12-14. 
of this institution..$^{19} \mathrm{~A}$ view was also expressed that the state essentially exploits the desire to enrich oneself through gambling, therefore public income from this source is doubtful from a moral point of view and if it were certain that "no other, even worse way to the satisfy the desire for gambling would be found", gambling should be given up. ${ }^{20}$ The basic function that was attributed to the lottery monopoly existing in Poland in the interwar period was not a fiscal, but a stimulating and protective function aimed at ensuring a state-controlled form of entertainment that would primarily satisfy the propensity to gamble, while providing a source of budget revenues. It is worth noting that in the literature on the subject, the method of obtaining income from gambling houses functioning in other countries was assessed in a similar way, ${ }^{21}$ but much less criticism was levelled against the gambling or betting tax, which, as a special tax on excessive consumption was a source of income for municipalities. The role of the stimulating function was also emphasised for all gaming taxes, indicating that it is a means of counteracting the dissemination of this kind of forms of human activity.22

After the Second World War, attempts were made in the "socialist camp" to minimise and even eliminate the importance of the fiscal function of taxes, stressing above all their extra-fiscal functions. However, it should be emphasised that although organising and participating in gambling was not accepted in the light of the rules of the socialist way of life, the state did not resign from public revenues from the above-mentioned source, and obtained them, among other things, by imposing turnover tax on this type of business. It is obvious that this levy also served to implement non-fiscal functions, with two major trends observable in this regard. On the one hand, the scheme of a turnover tax was used to shape patterns of socialist morality, which was reflected, among other things, by tax advantages for sports betting in comparison with horse race betting, which was perceived as a form of entertainment created by the Polish Sanation elite. ${ }^{23}$ On the other hand, state enterprises offering gambling of a universal nature were promoted, and the profits from them

19 See L. Biliński, System nauki skarbowej a w szczególności nauki o podatkach, Lwów 1876, pp. 68-72 and the literature referred to therein; S. Głąbiński, Wykład nauki skarbowej, Lwów 1894, pp. 259-260; I. Weinfeld, Skarbowość polska, Warszawa 1931, p. 111.

20 See R. Rybarski, Nauka skarbowości, Warszawa 1935, pp. 341-343. See also T. Jakubowski, Monopol loteryjny, [in:] Pięć lat na froncie gospodarczym 1926-1931, Vol. II, Warszawa 1931, p. 301; J. Kulski, Możliwość rozwoju podatków pośrednich, [in:] Pięć lat na froncie gospodarczym 1926-1931, Vol. II, Warszawa 1931, p. 240.

21 See S. Głąbiński, Wykład nauki..., pp. 260-261.

22 See idem, Nauka skarbowości z dodatkiem o skarbowości Austryi i Galicyi, Lwów 1911, p. 466.

23 In the 1960s and 1970s, Państwowe Tory Wyścigów Konnych (state horse racing course enterprise) paid turnover tax on state-owned companies in the amount of $8 \%$ of the turnover, while the state enterprise "Totalizator Sportowy" companies paid 1\% of the turnover. 
played an important role in financing both for tasks typical of a socialist state, such as financial assistance for social acts or investment of social economy enterprises, and for sports promotion, ${ }^{24}$ and later also for culture. An important criterion determining the amount of the imposed betting and gambling tax was also the status of the entity organising a given type of gambling or lottery, which was reflected in particular in tax exemptions enjoyed by the Polish Lottery Monopoly and in tax advantages of lotteries organised by the state-owned enterprise - Totalizator Sportowy in comparison with similar undertakings organised by enterprises appointed by local state administration bodies. ${ }^{25}$

Nowadays, most betting and gambling taxes in the European countries take the form of selective turnover taxes, which means that, in principle, these duties can be assigned functions similar to those that are performed by excise duties. In contrast to value added tax and other forms of general turnover tax, non-fiscal functions ${ }^{26}$ of gaming tax are also emphasised apart from the basic fiscal objective, and the subject of taxation alone covers activities subject to special state control.

\section{The stimulating function of the betting and gambling tax in the Polish legislative practice}

Switching to the Polish regulations, it should be pointed out that gambling and betting laws were based on the assumption that the regulations contained therein should serve only the real, non-stimulated social demand for gambling. On the other hand, the taxation of gambling with a separate gaming tax was to result in a higher fiscal burden of this sector, which was justified by the specifics of the gambling business, claiming that "gambling and lotteries do not belong to the sector of product

24 After the establishment of the Central Fund for the Development of Physical Culture and Sport in 1978, the profit of Totalizator Sportowy also supported this Fund. See Resolution No. 180 of the Council of Ministers of 8 December 1978 on the Central Fund for the Development of Physical Culture and Sport and voivodeship funds for the development of physical culture and sport (Official Gazette of the Government of the Republic of Poland, No. 39, item 149).

25 "Totalizator Sportowy" companies paid turnover tax on state-owned companies in the amount of $1 \%$ of the turnover. For enterprises operating local branches of the lottery business, the tax rate was initially set at $5 \%$, but as from 1 January 1982 it is $6 \%$ of the turnover.

26 See S. Cnossen, Economics and Politics of Excise Taxation, [in:] idem (ed.), Theory and Practice of Excise Taxation. Smoking, Drinking, Gambling, Polluting and Driving, Oxford 2005, pp. 3-6; S. Miller, C. Ludeña, op. cit., pp. 213-219; R.W. McGee, op. cit., pp. 231-237. 
production, but to the redistribution of players' income" ${ }^{27}$ It is also worth noting that although in the wording of the explanatory memorandum there was no reference to the issue of determining the tax amount in relation to particular categories of gambling, the analysis of the views expressed during parliamentary work shows that, as a rule, no function limiting supply and demand for any particular gambling services was attributed to gaming tax. On the contrary, the experience of the first years of operation of the gambling sector in a free market economy, and in particular the fact that no available location limits for the establishment of casinos and gaming machine arcades were used, gave rise to implementation of changes primarily with a view to generating more favourable conditions for the development of this sector. ${ }^{28}$ Introduced in 1997, progressive taxation of gambling organised in casinos and gaming arcades was therefore not to limit, but to stimulate the development of the gambling market. Subsequent amendments to the regulations governing the betting and gambling tax, including the act restoring the taxation of casinos and gambling arcade on a proportional scale, and the amendment extending the gambling catalogue for taxation by adding video lotteries, telebingo (TV bingo) and gaming machines with low prizes were justified primarily by fiscal, not social reasons. ${ }^{29}$ An intention to perform the stimulating function of the gaming tax in a positive sense can also be seen in the adoption of a $2 \%$ tax rate for betting on sport competition of animals, which is much lower than the other taxes. It is clear from the legislative materials that this change was designed in co-operation with the Ministry of Agriculture and Food Economy, and the primary objective of the tax advantage for such establishments was to support Polish horse breeding. ${ }^{30}$

The fundamental change in the gambling policy, and hence in the functions attributed to the gaming tax, took place as late as in 2009, which was reflected in the adoption of the gambling law that is currently in force. ${ }^{31}$ As already pointed out,

27 Statement by Member of Parliament Bogdan Łukasiewicz during the meeting of the Committee on the Economic Policy, Budget and Finance and the Legislative Committee on 20 February 1992, Bulletin No. 196/Sejm of the first term, p. 4, Sejm Archives.

28 See Explanatory Memorandum to the government bill amending the Act on gambling and betting and amending the Fiscal Penal Act, Parliamentary Paper No. 1256, Sejm of the second term, pp. 4-5, Sejm Archives.

29 See Explanatory Memorandum to the government bill amending the Act on gambling, betting and slow machines and amending the certain other acts, Parliamentary Paper No. 771, Sejm of the second term, p. 18.

30 See statement by the Undersecretary of State in the Ministry of Finance, Jan Bogutyn at the meeting of the Committee on the Economic Policy, Budget and Finance, the Committee on Youth, Physical Culture and Sport and the Legislative Committee on 16 May 1996, Chancellery of the Sejm. Information Office. Bulletin No. 2593/Sejm of the second term, p. 29, Sejm Archives.

31 The Act of 19 November 2009 on gambling (i.e. Journal of Laws of 2018, item 165). 
in the explanatory memorandum of the bill of this act, it was explicitly stated that the basic functions of the betting and gambling tax are fiscal and regulatory functions, however without developing this statement. The changes in the betting and gambling tax, just like other provisions of the Act, were to serve two basic purposes. The first one, defined directly by the authors of the bill as a "moral and social" reason, was associated with limiting the availability of gambling in Poland, primarily by excluding the possibility of organising gambling on gaming machines outside casinos. ${ }^{32}$ It is worth noting that this goal was also to be achieved, apart from administrative instruments, by increasing the flat rate of low-prize betting and gambling tax on gaming machines. When assessing the financial consequences of this change, it was assumed that unprofitable machines would be taken out of service. ${ }^{33}$ Another modification in the structure of the betting and gambling tax to which non-fiscal functions were unambiguously attributed was the introduction of new rules for taxation of poker played in the form of a tournament, in particular imposing a tax obligation on gambling participants and determining the rate for this gambling in the amount of $25 \%$ of winnings. Recognising that the specifics of poker make it possible for players to freely determine the course of the game, it was assumed that setting a betting and gambling tax rate higher than the arithmetic average of personal income tax rates would prevent "money laundering in this game". ${ }^{34}$ However, the imposition of tax obligation on the participants of gambling, the tax base structure and the tax rate lead to the conclusion that the aim was actually to limit this form of gambling. ${ }^{35}$ It should be pointed out that in countries with rich traditions in the organisation of international poker tournaments, the tax burden is usually on the organisers, while the tax base is the commission for organising the game, usually determined as an amount representing a percentage of the sum staked by players in one deal or one game ${ }^{36}$.

A change involving the inclusion of audiotext lotteries in the scope of the betting and gambling tax was supposed to bring about another effect. In this case, it was assumed that the determination of the tax rate of $25 \%$ of revenue should not constitute a limitation for the development of this market sector because the vast majority

32 See statement by Minister Michał Boni at the meeting of the Public Finance Committee (No. 231) on 18 November 2009, Bulletin No. 2986/VI, p. 4, Sejm Archives.

33 See Explanatory Memorandum to the government bill on gambling, Parliamentary Paper No. 2481, Sejm of the fourth term, Sejm Archives, p. 61, hereinafter referred to as the Explanatory Memorandum contained in Paper No. 2481.

34 Ibidem, p. 38.

35 For more see M. Duda, Taxation of Poker Winnings in Polish Tax Law, "Review of Comparative Law" 2009-2010, 14-15, p. 127-143.

36 Rake, commission fee. 
of audiotext lotteries organised up to 2010 were an addition to the core business and were aimed at making the non-gambling offer more attractive. Analysis of the contents of the explanatory memorandum to the bill and legislative materials also does not provide grounds for formulating a thesis that changes leading to increased tax rates for gambling organised in casinos are supposed to reduce the supply of gambling services. On the contrary, when designing the act, a relatively high growth rate of casinos was assumed due to the expiration of permits for operating gaming machine arcades and low-prize gaming machine arcades. In the context of the stimulating function of the betting and gambling tax, it may be surprising that tax rates for cash bingo and telebingo were raised by 15 and 10 percentage points respectively in a situation where cash bingo was organised in only one arcade, and telebingo was not organised at all in $2009 .{ }^{37}$ In this regard, the contents of the explanatory memorandum were limited to the information that the change was supposed to perform a consolidating function for the previously applicable fees for admission to a gambling centre, yet such consolidation actually did not take place, but the increased tax pushed this form of gambling out of the market. ${ }^{38}$

In the light of the official position of the Council of Ministers, the amendment to the Gambling Act of 2011, which introduced the possibility of organising bets via the Internet was also to serve the implementation of non-fiscal objectives. ${ }^{39}$ According to the explanatory memorandum to this bill, its main purpose was: "to increase the lawfulness and protection of the society from the negative effects of gambling". ${ }^{40}$ Referring to the established jurisprudence of the Court of Justice of the European Union, the scope of introduced restrictions was justified by the "overriding interest of the public", the need to preserve public order and the need to counter gambling addictions, ${ }^{41}$ whereas the limitations of the possibility of organising online gambling only to betting was justified by indicating that these games were not included in

37 See Information on the implementation of the Act on gambling and betting in 2009, Warszawa 2011, https://www.finanse.mf.gov.pl/inne-podatki/podatek-od-gier-gry-hazardowe/raportyroczne (access: 16.12.2016).

38 See the Explanatory Memorandum contained in Paper No. 2481, p. 63.

39 Act of 26 May 2011 amending the Act on gambling and certain other acts (Journal of Laws, No. 134, item 779).

40 See Explanatory Memorandum to the government bill amending the Act on gambling and certain other acts, Parliamentary Paper No. 3860, Sejm of the second term, pp. 1-2, hereinafter referred to as the Explanatory Memorandum contained in Paper No. 3860.

41 For more on the rules of restricting online gambling, in particular betting, in the CJEU case-law, see: J. Łacny, Gry hazardowe w Internecie - ustępstwo wobec swobód rynku wewnętrznego?, "Europejski Przegląd Sądowy" 2012, 1, pp. 15-21; A. Kaburakis, European Union Law, Gambling, and Sport Betting: European Court of Justice Jurisprudence, Member Stares Case Law, and Policy, [in:] J.S. Blackshaw, R.C.R. Siekmann, J. Soek, P.M. Anderson (eds.), Sports Betting: Law and Policy, The Hague 2012, pp. 27-94. 
the "hard" gambling and involved fewer social risks. ${ }^{42}$ It should also be emphasised that by introducing regulations that form the legal basis for organising bets via the Internet, the legislator was not guided by the need to create a legal framework for the development of a competitive market for this type of gambling and hence for a significant increase in the number of taxpayers on this account. ${ }^{43}$ Apart from unambiguous statements of representatives of the Ministry of Finance, this is evidenced by the fact that despite fully justified reservations made by the Association of Employers and Employees of Betting Companies and the European Gaming and Betting Association, ${ }^{44}$ there were no changes leading to the transition from a revenue-related tax base to the difference between the sum of paid stakes and the sum of paid winnings. When assessing the effects of this Act, it was assumed that the implemented changes would make it possible to generate additional tax revenues by entities that have organised betting in betting offices so far. ${ }^{45}$

The second category of modifications that are worth noting in the context of the stimulating function of the betting and gambling tax is the adoption of regulations that establish the legal bases for organising small raffle lotteries and small raffle bingo games on the basis of an application, while exempting businesses organising this type of gambling from the betting and gambling tax in question. ${ }^{46}$ Changes in this regard were introduced in the government bill amending the Gambling Act and certain other acts, submitted to the Sejm on 11 January 2011, at the stage of legislative work in the Senate, ${ }^{47}$ and the basic grounds justifying their adoption was the widespread problem of organising raffles in breach of the regulations of the Gambling Act. It may be surprising in this respect that during the debate on the introduction of the possibility of organising small raffle lotteries and small raffle bingo games on the basis of an application, no reference was made to the exemption of these games from the betting and gambling tax. The context of the introduction of the above-mentioned regulations justifies the supposition that the resulting

42 See the Explanatory Memorandum contained in Paper No. 3860, pp. 1-2.

43 See statement by Undersecretary of State in the Ministry of Finance Jacek Kapica at the extraordinary subcommittee meeting to consider the government bill amending the Act on gambling and certain other acts on 15 March 2011, sound record, Sejm Archive.

44 European Gaming and Betting Association (EGBA).

45 The proceeds from this were estimated at ca. PLN 52 million per year. See the Explanatory Memorandum contained in Paper No. 3860, p. 37.

46 Article 1(2) of the Act of 26 May 2011 amending the Act on gambling and certain other acts (Journal of Laws, No. 134, item 779).

47 See Resolution of the Senate of the Republic of Poland of 12 May 2011 on the Act amending the Act on gambling and certain some other acts, http://ww2.senat.pl/k7/pos/076/076porz.htm (access: 20.11.2017). 
modification of the scope of the betting and gambling tax was to create an additional legal incentive encouraging to organise gambling the proceeds from which are entirely intended for socially useful purposes in accordance with the regulations of the Gambling Act.

The amending Act of 2016 under which the catalogue of gambling games and lotteries that can be organised online was extended did not introduce changes in the regulations governing the personal field of application and quantitative elements of the betting and gambling $\operatorname{tax}_{,}^{48}$ but it should be pointed out that, in the opinion of the Minister of Finance, the above-mentioned solution was justified by the fact that such modifications could delay the work on this Act for several years. ${ }^{49}$ It should also be noted that during the legislative process, authors of the bill stressed that the purpose of the Act under consideration was not to increase the tax efficiency of the betting and gambling tax, which was to be reflected by the lack of amendments to regulations directly relating to tax issues. ${ }^{50}$ However, such argumentation is difficult to agree with because the Act significantly extended the scope of gambling games and lotteries that are subject to taxation, imposing the levy not only on online versions of some of these undertakings that so far could be organised only in betting offices, but also on games corresponding to the rules of games on gaming machines but organised via the Internet and multi-jurisdictional games. Therefore, it seems that apart from the objectives indicated in the explanatory memorandum, i.e. the need: "to reduce the occurrence of the 'grey market' in gambling, to ensure the highest level of protection of players against the negative effects of gambling and to raise public awareness of the threats arising from using the services of illegal gambling operators", ${ }^{11}$ this Act was also intended to increase the tax efficiency of the gaming tax. Just like in the case of the amendment that introduced an opportunity to organise bets via the Internet, the goal of the introduced changes was not to create a competitive e-gambling market, and thus to introduce such modifications in the elements of the gaming tax scheme, so that it could provide an incentive for

48 Act of 15 December 2016 amending the Act on gambling and certain other acts (Journal of Laws of 2017, item 88).

49 See statement by Wiesław Janczyk Secretary of State in the Ministry of Finance at the extraordinary subcommittee meeting to consider the government bill amending the Act on gambling and certain other acts (Paper No. 795) on 4 March 2016, sound record, http://www.sejm.gov.pl/SQL2. nsf/poskomprocall?OpenAgent\&8\&795 (access: 1.09.2017).

50 See statement by Wiesław Janczyk Secretary of State in the Ministry of Finance during the second reading of the government bill amending the Act on gambling and certain other acts, a stenographic report on the $32^{\text {nd }}$ Sejm meeting on 14 December 2016, p. 211.

51 Explanatory Memorandum to the government bill amending the Act on gambling and certain other acts, Parliamentary paper No. 795, Sejm of the eighth term, p. 1, hereinafter referred to as the Explanatory Memorandum contained in Paper No. 795. 
foreign operators to apply to Polish authorities for licences. The implementation of such a goal, in addition to limiting the scope of the state's monopoly, would have to include modifications of tax regulations that determine the betting and gambling tax rate. In particular, it would be necessary to depart from the revenue-related tax base in the case of bets organised via the Internet and to lower the tax rate and make it possible to aggregate tax bases for casino games organised in e-casinos.

To sum up the comments on the assumptions regarding the stimulating function of the betting and gambling tax, it is also worth noting that by liberalising the rules governing the organisation of poker games, a tax exemption was implemented for the business of organising poker tournaments by entities that do not have a licence to operate a casino. The contents of the explanatory memorandum indicate that the creation of a legal basis for organising this type of tournaments is a partial implementation of the suggestions of the poker community and is aimed at making it possible to organise sport poker tournaments the idea of which is based on sports competition for symbolic material winnings. ${ }^{52}$ Therefore, the assumption above leads to a conclusion that, just like in the case of small lotteries, the exemption from taxation for activities involving the organisation of this type of undertakings was supposed to provide an additional incentive to organise poker tournaments in compliance with the regulations of the Gambling Act.

\section{Final remarks}

The betting and gambling tax belongs to levies to which non-fiscal functions are explicitly attributed, with the most frequent one being historically the stimulating function, which boils down to hampering the phenomena thought to pose threats in the social and economic sphere. In this context, the gaming tax has, therefore, features similar to selective turnover taxes, in which the tax covers the trade in goods commonly recognised as harmful or dangerous. Negative incentives are provided in two dimensions. First, betting and gambling tax schemes can be used to reduce the demand for gambling services by influencing the choices of potential gambling participants. Second, betting and gambling taxes may be an instrument to limit the supply of gambling services by imposing higher taxes on entities operating in this area than those used in other sectors of the economy, in particular in other sectors of entertainment services. As a result of recent changes in the perception of gambling, which is increasingly treated as one of the forms of adult entertainment, there is also a tendency to attribute a stimulating function in a positive sense to betting

52 See the Explanatory Memorandum contained in Paper No. 795, pp. 14-15. 
and gambling taxes, with a view to stimulating some forms of gambling and creating incentives aimed at encouraging foreign operators to apply for permits and invest in a given country.

In the Polish legal tradition, both the lottery monopoly and the taxes charged to entities operating a business involving the organisation of gambling were intended to perform a stimulating function, with negative incentives being the most popular ones in the interwar period. Taxation of gambling services was treated as a measure to counteract the spread of gambling. On the other hand, in the period of Polish People's Republic, the structure of the turnover tax was used to shape patterns of socialist morality. state enterprises offering gambling of a universal nature were promoted, and the profits from them played an important role in financing both for tasks typical of a socialist state as well as sports and culture.

The analysis of the regulations governing the betting and gambling tax nowadays and the legislative materials created in the process of their creation leads to the conclusion that a stimulating function was attributed to this levy in all the above-mentioned dimensions. In the period in which the Act on gambling and betting was in force, the function of limiting the demand and supply of gambling services in principle was not attributed to the betting and gambling tax. On the contrary, further changes in the elements of the structure of this levy were intended to generate more favourable conditions for the development of this sector of the economy. Incentives in a positive sense can also be seen in the adoption of a $2 \%$ tax rate for betting on the sport competition of animals, which is much lower than other taxes. The functions of limiting the supply and demand for gambling services have unambiguously been attributed to the gaming tax since the entry into force of the Gambling Act, which was obviously associated with a change in the direction of the gambling policy. In addition to a significant increase in the flat rate of low-prize gaming machine betting and gambling tax and the introduction of unfavourable rules - both from the point of view of players and entities organising the games - for taxation of poker in the form of tournaments, this type of intervention was reflected by an increase in rates for bingo, with the function actually performed by this tax in the latter case was in clear contradiction to the objectives declared in the explanatory memorandum to the bill. It is also significant that, unlike in countries with rich traditions in the regulation of online gambling, the structure of the Polish betting and gambling tax is not used to create incentives to apply for permits to operate gambling business by foreign operators. On the other hand, positive incentives can be seen in the exemption from tax for the business of organising small raffle lotteries, small raffle bingo games and poker tournaments by entities that do not have a licence to operate a casino, which in part seems to be a response to the suggestions of both non-governmental organisations and the poker community. 